DOI 10.17516/1997-1370-0832

УДК: 181.161.1’282.8

\title{
Linguacultural Interactions in Orenburg Region
}

\author{
Elena N. Bekasova* \\ Orenburg State Pedagogical University \\ Orenburg, Russian Federation
}

Received 29.08.2021, received in revised form 02.09.2021, accepted 14.09.2021

\begin{abstract}
The sub-dialects in the territories of later settling are of special research interest due to the specifics of interdialectal and foreign contacts and the influence of extralinguistic factors, which determine the relevance of lingua-cultural researches. In this regard, the Orenburg region, being established as a territorial district on a wide frontier area, makes it possible to trace the peculiarities of forming and intercrossing of numerous transmigratory sub-dialects, which were in an active contact with the Turkic and Finno-Ugrian languages. It is documented with the lexicographical material, presented in the dictionaries by V.I. Dahl, N.M. Malech and B.A. Moiseyev, as well as by the records of sub-dialectal speech from the 1950-1970s and up to the early XXI century, which makes it possible to trace the main parameters of the linguacultural interaction of social and ethnical groups, evaluate the limits of engaging dialectal systems for Turkic borrowings and determine their lexical sets, allowing to eliminate the lacunae in the traditional transmigratory culture which has undergone many changes. Being directed at a more prestigious social group, - primarily, the Orenburg Cossacks, the borrowings of cattle-breeding terminology and the words for foods show the stages of forming the relations which lead the consultants and scholars to understanding the unified commonality of the local population.
\end{abstract}

Keywords: secondary transmigratory dialects, territories of later settling, Orenburg Russian dialects, borrowings, Turkic languages, language contacts.

On the threshold of his 96th birthday we would like to express appreciation to B.A. Moiseyev, Orenburg's famous historian, toponymy scholar and dialectologist, without whose works the research of Orenburg's linguistic space would be impossible.

Research area: linguistics, russian language.

Citation: Bekasova, E. N. (2021). Linguacultural Interactions in Orenburg Region. J. Sib. Fed. Univ. Humanit. soc. sci., 14(10), 1474-1485. DOI: 10.17516/1997-1370-0832

(C) Siberian Federal University. All rights reserved

* Corresponding author E-mail address: bekasova@mail.ru 


\title{
Лингвокультурные взаимодействия на территории Оренбуржья
}

\author{
Е.Н. Бекасова \\ Оренбургский государственный педагогический университет \\ Российская Федерачия, Оренбург
}

\begin{abstract}
Аннотация. Оренбургские русские говоры, складывающиеся на обширной территории в условиях активных процессов междиалектных и межъязыковых контактов, представляют интерес не только как материал изучения формирования и развития систем переселенческих диалектов, но и в аспекте лингвокультурных взаимодействий на территории позднего заселения. Анализ записей диалектной речи 50-70-х годов XX в., а также словарей В. И. Даля, Н. М. Малечи, Б. А. Моисеева дают возможность реконструировать особенности заселения края, направления интерференционных процессов в зависимости от отношений социальных и этнических групп в пределах поселений. Выявленные тематические группы заимствований позволили определить причины их появления в говорах переселенцев и соответствующие изменения в системе традиционной обиходной материальной и духовной культуры в условиях контактирования народов, которые способствовали постепенному формированию осознания единства местного населения, выраженного специфическими терминами общности.
\end{abstract}

Ключевые слова: вторичные переселенческие говоры, территории позднего заселения, оренбургские русские диалекты, заимствованная лексика, тюркские языки, языковые контакты.

На пороге 96-летия ученого мы хотели бы выразить признательность Б. А. Моисееву, известному историку Оренбурга, топонимику и диалектологу, без чьих работ исследование лингвистического пространства Оренбурга было бы невозможно.

Научная специальность: 10.02. 01 - русский язык.

\section{Introduction}

The secondary sub-dialects present particular interest in connection with the forming of the special dialectal systems, disconnected from the original corpus and being unfolded 'in the conditions of intensive interdialectal and often interlingual contacts' (Barannikova, 2005), which, to one degree or another, allows to determine the mechanisms of interaction between various linguistic strata under new historical conditions. As a rule, the territories populated by, as I. A. Baudouin de Courtenay put it, 'an ethnographical mix', show 'the so-called natural course of events, rid of deliberate influence of administrative authorities and other political and social factors, relying on various preventative and preceptive measures' (Baudouin de Courtenay, 1963). It determines the significance of researching the processes of interference, the specifics of permeability of the sub-dialect system and the variety of the inventory of the borrowed linguistic units, their correlation with the original correspondences and the degree of their intactness. These conditions presuppose the complications in researching and classifying the secondary sub-dialects, in regard to the entity of linguistic and extralinguistic factors. Moreover, systemic studying of the secondary Russian sub-dialects only began in late 1970s and as of today it has not sufficiently covered the territories of later settling. Unfortunately, notwithstanding certain achievements in researching the secondary Russian subdialects and contactology (as in the works of L. I. Barannikova, O. I. Blinova, V. E. Goldin, 
L.E. Kalnyn, L.L. Kasatkin, O. Yu. Kryuchkova, S. A. Myznikov, B. B. Palagina, V. I. Suprun, L. G. Samotik at al.), the peculiarities of secondary sub-dialects and insufficient resource base for their research allow us to believe that 'we only have very shallow understanding of linguistic landscape in territories of later settling' (Bazhenova, 2016).

\section{Statement of the problem}

It's especially important to study the under-investigated secondary Russian subdialects in territories of later settling and the significant aspects of their formation and development. In this regard, the sub-dialects of the rather vast Orenburg region area, historically representing a bigger territorial entity of the Russian empire, from the beginning of its establishment has been a special zone of ethnical, cultural, confessional and linguistic interaction, which was presupposed by active migratory processes as well as the extending frontier line, which is still true as of today. The reclamation of an enormous area, which since 1744 included the modern territories of Orenburg and Chelyabinsk oblasts, parts of Kurgan, Samara, Perm, Tyumen and Sverdlovsk oblasts, Tatarstan, Bashkortostan, north and west Kazakhstan, was characterized by several waves of migrants (not only from west to east, but also from the territories of Ural and Siberia to the already reclaimed lands) and it went along with interactions among settled and nomadic Turkic and Finno-Ugrian peoples.

V.I. Dahl was the first to point out the peculiarities of the dialectal landscape of Orenburg governorate, having summarized the conclusions of the 8-year long (1833-1841) observation of the Orenburg 'parlance': 'Orenburg governorate, originally populated by foreigners, mostly nomadic, became filled with Russians from twenty governorates in the past hundred years; that is why there is not any common dialect in this governorate; however, the old inhabitants have already formed a few special features' (Dahl, 2000, v. I); 'In Saratov and Orenburg governorates, populated in this century, and partly recently, by descendants of twenty governorates, it is very easy to discover the migrants' origin by their parlance; it is more difficult when the elderly have passed away, while the young ones get gradually used to the local dialect, even more so if the settlement is diversely populated by people from different areas, and the youth accommodated and got accustomed to it' (Ibid.).

Later the Orenburg Russian sub-dialects came into the researchers' attention only in the XX century, while the main directives in studying the Russian language on the territory of Orenburg oblast, outlined by V.I. Lytkin, N.A. Meschshersky, V.G. Rudelyov, D. K. Zelenin and N.I. Zorin, were still relevant and remain so up to today, and were generally realized in the research works of B. A. Moiseyev, who, in late 1970 s could compose the chrestomathy of Orenburg Russian sub-dialects and 'the dictionary of Orenburg oblast'.

It became possible to publish those works only in the XXI century, allowing the author to augment and revise them (Moiseyev, 2005; $2010 ; 2019)$, as well as prepare works on Orenburg toponymy (Moiseyev, 2013; 2016). As a result of this, the scientific community was presented with novel material, containing the records of dialectal speech, collected through $1950 \mathrm{~s}-1980 \mathrm{~s}$, around 7000 words and word combinations along with the description of main toponymic units of the Orenburg region, which enabled researching of the specifics of Orenburg's dialectic and onomastic spaces. In this regard it is enough to refer to the collections of articles of the Moiseyev's readings, established for B. A. Moiseyev's $80^{\text {th }}$ birthday in 2015 (Vestnik, 2015; Fourth Moiseyev's Readings, 2018; Fifth Moiseyev's Readings, 2019; Sixth Moiseyev's Readings, 2021).

However, despite all the material currently existing in the scientific possession, dialectal and onomastic spaces of the Orenburg region demand being actively studied. In particular, S. A. Myznikov, who pointed out how necessary it is to study the linguistic landscape of the Orenburg region in 2010 (Myznikov, 2010), addressed to the under-investigation and topicality of the linguistic specifics of the region in regard to the Orenburg Russian dialects during the Fifth Moiseyev's Readings in 2018 (Bekasova, Yakimov, 2019). 


\section{Methods}

It goes without saying that every aspect of investigating the secondary sub-dialects represent a unique phenomenon, connected with the peculiarities of the formation of new Russian sub-dialects on a large territory in different time periods, in different ways and under unequal linguistic and non-linguistic conditions. While using the traditional methods of investigation for the dialect systems (descriptive, contrastive-comparative, lingua-genetic, etc.), investigating the secondary sub-dialects demands special attention paid to extralinguistic factors, the parameters of the language situation and the problems of contactology. Considering the fact that the most intact part of the secondary sub-dialect system is vocabulary, the investigation involved the principle of systemic lexical description. However, the aims of the article presupposed the angle of studying the lingua-cultural interaction on the territory of later settling, meaning to investigate the transformation of traditional habitual material and spiritual cultures under the conditions of interacting peoples, which were previously geographically, ethnically, and confessionally isolated.

\section{Discussion}

Mass migration to the territories of Orenburg governorate began in the second half of the XVIII century, when the descendants from the traditional settlement areas faced a number of difficulties in connection with the peculiarities of the frontier land (which was often disturbed), extreme continental climate along with special natural features and interactions with the Turkic peoples. Several waves of migration determined the territories inhabited with 'the old residents' being gradually filled with the newcomers, which often caused linguacultural opposition, quite clearly reflected in the memories of the consultants.

In this regard, the attitude towards aliens in one of the preserved old settlements, which is rare for Orenburg oblast, - Gorodishche (a former Cossack village, founded in 1800) is very illustrative. The descendants of the Orenburg Cossacks, who firmly believe in their elitism, has kept the nickname for all the newcomers -
'Наплывь' [naplyv] (those who flowed in; cf. 'everything that flowed in was brought with water' (Dahl, 2000, v. III)). There is more jargon for the newcomers. For example, B. A. Moiseyev points out that the Cossacks, descendants of the Orenburg stanitsas (big Cossack villages), who founded their own settlement next to the Elshan outpost in the early XIX century, used the word 'raznochinets' (the commoner, or a XIX century Russian intellectual not belonging to the gentry) for referring to Russian and Ukrainian peasants, who, having moved to the Cossack Elshanka, had to rent the lands from the Cossacks (Moiseyev, 2016).

A certain antipathy in the attitude of Cossacks to the peasants is a very common phenomenon, which, as a rule, is lingua-culturally motivated. In particular, B. A. Moiseyev notes the situation in Grigorievka settlement in SolIletsk region, which was originally populated by 'the Cossacks with okanie (pronunciation of unstressed [o] as [o] in Russian dialects). After a while the migrants from Voronezh and Kursk governorates came and volunteered to become Cossacks. Their sub-dialect with akanie (pronunciation of unstressed [o] as [a]) possessed a few very distinct features: yakanie (pronunciation of unstressed vowels as [ya]), the absence of the consonant [f], etc., which were always ridiculed by the initial inhabitants. The Cossacks, who moved there earlier, prone to okanie, gave all the directions to the military activities, householding, and social life. They believed their subdialect to be the exemplary speech and tried to protect it. Under these conditions many features of akanie (such as yakanie and the affricate [g]) gradually disappeared' (Moiseyev, 2019).

Such patterns are quite common, because, as it was pointed out by L.I. Barannikova, under the conditions of inequality among the migrants in territories of later settling there is 'a willing to mirror the elite groups of population', when in 'the sub-dialects present along the Ural river' L.I. Barannikova notes 'the wellknown to dialectology cases of mimicking the neighbours, when the non-Cossack population imitated the Cossacks' (Barannikova, 2005).

A similar case in the Orenburg region was first described by D.K. Zelenin (1905), 
who, characterizing the sub-dialect of the Cossack settlement Blagoslovenka, stated that it was 'not a product of a blend' but 'a result of a victory of one of its components over all the others', while 'the lucky winner happened to be the Cossack sub-dialect (Orenburg and Samara Cossacks). The victory was witnessed by the local old residents - the original Cossacks...The same victory is proven by the equality of the Blagoslovenka sub-dialect and the sub-dialect of the oldest Cossack lineage - the right bank Cossacks' (Zelenin, 1905). D. K. Zelenin particularly notes that 'we have all the grounds to believe that the non-Cossacks who moved to Blagoslovenka, along with the Ukrainians and the Mordvins, deliberately chose the way their new neighbours Cossacks speak as a standard for their own pronunciation (Zelenin, 1905).

Such understanding of the Cossacks' everyday life, culture and sub-dialect as the most prestigious is presented over all the Orenburg region, however, there are known cases when non-Cossacks remained detached and isolated in their determination to preserve their traditional culture and language. Certain 'unpleasant relationships' between the founders, the peasants from Saratov governorate, and the Cossacks were spotted by B. A. Moiseyev in Saratovka settlement. This resentment resulted in these social groups being isolated from each other within one settlement. It must also be added that the Cossacks 'didn't like the peasant men and called them hurtful and offensive names: muzlan, muzlanye [rough country man, bumpkin]' (Moiseyev, 2019). The exemplary material of the Dictionary of Orenburg Oblast presents various aspects of resenting the neighbouring non-Cossacks. For example, «Мужики-музланы жили среди казаков» [The muzlans lived among the Cossacks], «... зря с музланом дружбу затеваешь. Мы, казаки, сами свои дела разберём» [... you shouldn't make friends with a muzlan, we, Cossacks, must mind our own business], «Эх вы, музлань́-грязныл» [Yои, unclean тиzlans], «Музланьё понаехало наши земли занимать» [The muzlanie flooded in to ocсиру our land], «Время-то какое, гольное музланьё везде в лаптях. И одолевают наших...» [What times are these, the rough muzlans are everywhere in their laptys, bothering our kin...] (Moiseyev, 2019, 250-251). We must also point out the semantic transformation of the lexeme in the records from 2012: [моја́ св’кро́в говор'ѐла / пр’ије́хал'и музло́ны на нашу з'е́мл'у / б’иссо́в'есныје прохло́пал’и в ладо́шы / a m’en'ép' говор'ѐm отн'има́јут у на́с з'е́мл'у / б’иссо́в'есныје музло́ны / ајаговор'уве́т' тыжэ пр'ије́хал'а на ста́нцыју / ты н’е на своје́й з'е́мл'e / вот / а пр’ије́хал'а на ста́нцыју / кака́jа рáзн'ица / ты ж то́жэ тогда музло́нка] (Yakimov, 2017). A female villager of 76 years old, speculating about 'the wonderers' - people, forced to migrate in times of Tsar and Stalin and now willingly changing their residence, criticizes her mother-in-law, who resented the aliens, and thus the context loses its negative and social connotation of the word 'muzlan', but the meaning 'the newcomer to an acquired land, an alien' becomes amplified.

There was tension among the migrant peasants as well. According to B. A. Moiseyev's findings, the Kursk peasants, who settled in Gamaleyevka settlement around 1930s, in a few years happened to be neighbours with Siberian peasants, who, having refused to become Cossacks, were forced to leave the Cossack lands. The relations between the Kuryaks (the Kursk peasants) and the Siberians were severely resentful: the Siberians did not take cattle or fowl from the Kuryaks, neither did they marry the Kuryak girls because they believed that those would become bad housewives (Moiseyev, 2016). When the Siberians complained, the Kuryaks would say: 'Сейчас в избе гадко, зато на столе будет сладко. К осени вся живность подрастёт, и на зиму будет мясо [The house is bad now, but the meals will be good. Come autumn, the farm animals will grow and we will have meat in winter]' (Ibid.).

This resentment towards everyday habits determined the existence of isolated ends of the settlement, - the Kursk (Kuryaks), the Siberian (Sibiryaks), and later the Khokhol (the Ukranian) end, where life was isolated for a long time, preserving the according dialectal differences.

Therefore, lingua-cultural clashes among the Slavic peoples could lead either to elimi- 
nating, or to preserving the differences in the traditional national culture and language.

The relationships between Slavic and Turkic peoples, who began interacting in the territory of Orenburg governorate, had many more complications. The records of 1950 1970s from nearly all around Orenburg oblast show evidence of hostile attitude between the two clashed peoples, for example: [Стьр'ѐк'и роска̀зъвъл'и, к'ирг'ѐзы удол'ева̀л'и их, скот'ѐну върова̀л'и; // ра̀н'шь байа̀л'ис' к'ирү'ѐсъфъ, в'а̊ч 'ьръм патскіิч'ут, аүра̀б'ут', пл 'а̊т'у (плетью) ат'а̀нут' и жа̀л'иццъ н'а̊къму //; К'ирг'ѐзы нъпада̀л'и, из-за йа̊фтъвъ нъ покі̂с выйежжа̀л'и вм'а̊c'т’и / а хті̂ н'и усп'а̊т скос'ѐт', упозда̀т, од'ѐн н'и йа̊д’ит: ф пл'а̊н бра̀л'и / об а̊тьм и ф п’а̊c'н'ь п’а̊лъс'; К’ирг'ѐссы наб'а̊г'и д'а̊лъл'и// йа̊сл'и ф пі̂л’ь нъч'ава̀т', то т'ил'а̊г'им'и, бр'ѐч'к'им'и, бърана̀м'и абгара̀жъвъл'ис'] (Moiseyev, 2005).

It must be noted that the migrants understood the reasons for this hostility: [Был к'ирг'ѐск'ий край // Ура́л къзак'ѐ зъхват'ѐл’и у тата́p // зд’ес' был л’ез др’имо́ч’ий // върава́л’и ро́ск’их, каза́к’и жи̂л’и ут'исн'ѐт'ьл'нъ; К'ирг'ѐзы, ан'å нарі̂т найа̊з'н'ик'и, а къзак'ѐ биิл'и п’ьхат'ѐнцы / к'ирг'ѐзы уган'а̀л'и скат'ѐну, жа̊ншшын / адна̀ жа̊ншшынъ с к'ирг'ѐзинъм жыла̀, срад'ѐлъ два р'еб'іิнкъ и уб'ижа̀ль атті̂л'а / ва вр'а̊м’ь жн'итва̀ фургі̂шкъм'и (повозками, фургонами) д’а̊лъйут кар’а̊йу (полукруг) / л'о́д’и ф с'ьр'ид'ѐнк'ь, а патро́л' хі̂д’ит наро́жы / в’ит' к'ирг'ѐзъв байа̀л'ис', ан'å нарі̂д бунтова̀тый] (Moiseyev, 2005).

With time, the neighboring people gradually developed tolerance towards each other, followed by mutual respect to distinct ethnic and linguistic features of their lives - 'axioms, common in every social or cultural group, defining good and evil, life and death, beautiful and ugly, which determined behavioural patterns, moral and ethical recommendations and prohibitions' (Panchenko, 2005). B. A. Moiseyev's records allow, to some degree, to reconstruct the main stages of this reconciliation between the peoples, which, according to Y.B. Myznikova, lead to the appearance of 'the model of special ethnocultural self-consciousness of the local population and establishment of tolerant attitude towards the representatives of other ethnic or religious communities', characteristic for Volga-Ural region (Myznikova, 2017).

In particular, in 'Toponymic essays of the Orenburg Region' B.A. Moiseyev writes up on the circumstances of peaceful coexistence of the Russian peasants and the Kazakhs on the territory of modern Pokrovka settlement, which began with equal trade conditions on the communal Dzhirenkupensky bazaar and understanding each other's speech. When the friendly relationships were set by becoming tamyrs - friends, or partners, 'in Russian subdialects along the river Ilek the word 'to tamyr' became wide-spead, which meant 'to be friends with the Kirghiz'. A fable, documented by B. A. Moiseyev in 1958, shows that on the right bank of the Ilek river there were the Cossack outposts and cordons, but the Russian peasant could only settle along the right bank, where the Kirghiz-Kaysacks were nomadizing, destroying the migrants' dug-outs with no chimneys, but then, the Kirghiz, charmed by the peasants' persistence, sent their Aqsaqal with an offer to become tamyrs and fight against the Kushpels and Adais, who raided the Ilek, together. The brotherly friendship between the Russian peasants and the nomadic Kazakh helped them protect themselves from the alien nomads and defend the friendly nomads from the Cossacks. According to numerous interviews with the old residents of Orenburg settlements, B. A. Moiseyev states that 'in the late XIX century and later tamyrstvo [friendship or partnership] between the Kirghiz and the Russians along the river Ilek became habitual' (Moiseyev, 2016), which is also proven with the illustrative material in the dictionary articles from 'the Dictionary of Orenburg Oblast', for example: 'the Kirghiz and the Urus [a Russian person] were friends', 'These Kirghiz were neighbours, they tamyred with Urus', 'The nearest didn't attack us, they were tamyrs back then', 'We were not tamyrs with the Adais, they attacked us and our tamyrs' and so on (Moiseyev, 2019).

Under the migrants' influence, the Kushpels (nomadic Kirghiz) became dzhataks (the settled Kirghiz), and there soon appeared the first eghenchi - the Kirghiz land cultiva- 
tors. Similar relationships took place among other peoples, too: [Наріิд жыл в дро́жб’ь 3 башк'ѐръм'и и мні̂гъ ѐх пъродн'ѐлъс' c ро́скым'и / и с'еч'àc йес'т' у на̀с фам'ѐл'ийа Хайі̂ръф / башк'ѐр жын'ѐл'с'ь на б'а̊днъй ро́скъй ба̀б'ь; Жа̀л'и с'ер'па̀м'и / и вот йав'ѐл'ис' с каса̀м'и тата̀ры, нън'имал'и их кас'ѐт' / б’аүóт' фс’à c’алî сматр'а̊т': кака̀йь удіิб’ийь - каса̀ /] (Moiseyev, 2005).

It goes without saying that 'tamyrstvo' [being friends] as a special form of linguacultural interaction had a positive effect on the lives of contacting peoples, enabling the exchange of accumulated experience and achievements of traditional cultures. A bright and authentic marker of accepting the realia of other peoples' everyday life is the borrowings in the Russian Orenburg sub-dialects, which covered the lexical gaps that appeared because of a certain 'lingua-cultural confusion' that the migrants had in a new and unhabitual environment and which they tried to fix by giving the new realia borrowed nominatives. At that, the thematic definition of the Turkic borrowings in the Russian Orenburg sub-dialects allows us to trace the sequence of how the people became closer.

In particular, the special features of household relationship with the nomadic Kazakhs, who had well developed herding in the conditions of the South Ural, contributed to the fact that a whole range of herding and cattle breeding terms were borrowed, while, as S.A. Myznikov points out, some of the borrowings transferred to the vocabulary of the Yaik Cossacks (Myznikov, 2018), and it could have been the way they were introduced to the speech of the migrant peasants. Therefore, while the non-equivalent vocabulary is mostly presented with the terms of camel husbandry (илюк, бутакан, куспак, инген, etc.), other terms of domestic animals for their age, colour type, breed and physical characteristics had equivalents in Russian sub-dialects, such as 'башмак, басмак’ [a 1-year old calf], 'башмачка, башмачина, тайка, тайчина, кошарка' [a 2-year old calf], (cf. годушка, годовик, второгодница, второгодник, etc.).

We dare to assume that in this case the Turkic borrowings were initially used to differ- entiate the cattle of local breeding, which was necessary to distinguish with terms, for example while trading (Bekasova, 2014). This idea is grounded not only by the fine semantic differentiation demanded by the dialects, which bordered with variability, coinciding with it later, but also by modern Orenburg contexts. This can be shown, for example, in how a Tatar person word their question, asking a strange woman about her child: 'Kyzymka [a little Asian girl, a daughter] or Russian?'. For a Tatar person it was important to find out the black-eyed child's nationality, that's why the word 'kyzym' gets an additional connotation - not just a girl, but a Tatar girl.

The potential of borrowed words was also very important for the Orenburg sub-dialects. In this regard we can refer to the word 'куян' $a$ hare], which was recorded by V.I. Dahl (Dahl, 2000 , v. II). In B. A. Moiseyev's dictionary is updated with a clarification - 'a hare, usually in word combinations like 'куян слепой' [а blind hare]' (Moiseyev, 2010). Our research of native Orenburg nicknames shows that a kuy$a n$ is referred to a single middle-aged man, a bachelor or a widower, who lives at the edge of the settlement. As a rule, in those settlements, usually of mixed national population, the old residents believe that this Kazakh/Tatar word meant a sturdy male hare, a lone hare (Bekasova, 2020). This also demonstrates one more meaning of the word, which, in our opinion, allowed it to remain in the Russian language and fill in an important lexical gap as a nominative. The history of the word 'kuyan' in the Orenburg sub-dialect makes it possible to justify reasons for borrowings: the borrowed word could have obtained a certain 'overtone' that were needed for the sub-dialect, which, in most semantically uneconomical manner described the world touching upon the smallest details.

However, a group of food terms is considered to be the most important among the Turkic borrowings in lingua-cultural regard. Existence of this group can be explained by the very tight connections between different ethnic groups and not only it supposed outside observation, but also it involved sharing meals as well as keeping to certain hospitality etiquette and having mutually relevant conver- 
sations, for example: 'Чем только не угощали нас киргизы (казахи): варили бишбармак, готовили кувардак [The kirghiz treated us to a lot of food - they made bishbarmak and cooked kuvardak]'; 'Здесь находится депутация от киргиз, которая хотела чествовать его (русского священника) самым почётным киргизским угощением кумызом и кургашиной [There is a Kirghiz deputy that wanted to honour him (the local priest) with the most honorable treat - kumyz and kurgashina]'. 'Раз пришли к ним, а они нас бижбармаком угостили [We visited them once and they treated us to bizhbarmak]'. 'Бывало мать часто варила бижбармак, но мы ложками ели, а киргизы - руками: возьмут рукой лепёшечку и кусочек мяса, положат в рот, потом ладошкой черпают жижку и запивают [Mother used to make bizhbarmak, but we ate it with spoons, and the Kirghiz - with their hands; they would take a piece of flatbread, then a piece of meat and put it in their mouth, and then they'd scoop some broth with their palm and drink]' (Moiseyev, 2019). [К'ирү'ѐзы (казахи) скат'ѐну ст'ер'а̊ч' уйа̊хъл'и / када̀ н'амні̂шкъ пъйад'àт', а паті̂м в’а̊ч’ьръм ч’ай п'йо́т' памні̂үъ / ръската̀йут' т' а̊стъ ті̂нкъ, пар'а̊жут' клака̀м’и (клочками), сва̀р'ут', рука̀м'и б'аро́т' и йед'а̀т' / а жиิшку ф ч’àшк'и нал'йо́т' и ч’ир'ис кра̀й п’йо́т' / к'ирү'ѐс н’и хл'аба̀йа, ліิжък н'ет у н'авî/] (Moiseyev, 2016). The example of 'Куда пропал наш хозяин, а он ушел к киргизам и там бижбармачит' [Where's our master? He went to the Kirghiz and he's bizhbarmaking there' (Moiseyev, 2019) is very illustrative. It shows that not only the traditional meals were introduced into the nutritive system of Russian migrants, which is proven by the fact that the verb is formed according to the Russian word derivation system from a borrowed root, but also that the relationship between the two different groups were quite friendly towards each other.

The names of foods and dishes compose the most significant group of borrowings both in quantity (more than $30 \%$ of non-equivalent vocabulary) and in quality - the degree of their intactness and the frequency of being used in the speech of Orenburg residents. Dishes made of grains, meat and milk give a positive characteristic to the national cuisine of the Kazakhs, Bashkirs and Tatars, for example буурсак [buursak] (rich fried balls or small squares of dough); белиш (беляш) [belish or belyash] (a round pasty stuffed with meat); казы [kazy] (horsemeat sausage); каймак [kaymak] (cream of boiled milk); катык [katyk] (sour milk) and so on (here and further the examples are from Moiseyev, 2019).

Borrowing Turkic dishes, the migrants would often change the ingredients and adapted the recipes to their own possibilities and preferences, for example: 'Кuиrdak [куурдак], or meat fried in fat is one of the Steppe Kirghiz's favourite delicacies'. 'Kuurdak - horsemeat or mutton chopped to small pieces and fried in melted fat'.- 'It's the way we make kuvardak [кувардак] - they chop potatoes, add liver and fry it with onions and fat'; 'In Linyovka kuvardak is chopped boiled potatoes with onions and fat'. 'All Tatars feed on salma [салма; a type of noodles], we make it too' - 'Salma is flour porridge, they call it 'zatirukha' in other places'; 'During the whole war we ate salma (a dish of potatoes and flour)'.

Names of dishes also undergo various processes of adaptation, such as 'бижбармак < бишбармак, бесбармак'; 'кувардак < куурдак'.

We must point out the transformation of the name of a Kazakh national dish 'коже (куже)' [kozhe (kuzhe)] into Russian 'кузя' [kuzya]: 'They made kuzya - millet and milk'. 'Millet porridge made on sour milk is called kuzya'.

Some of the borrowed dishes were so firmly present in the nutritive culture of Orenburg residents, including Russians, that they became a sort of specialty for the local cuisine with the characteristics of family or territorial recipes. 'Bizhbarmak' is especially popular, despite the fact that in V.I. Dahl's dictionary it has a rather negative description: 'Of a badly cooked meal one could say 'it's such a bizhbarmak, medley]' (Dahl, 2000, v.1).

The findings collected by B.A. Moiseyev, convincingly demonstrate the processes of 'claiming' alien culinary culture, for example: 'All Tatars feed on salma, we make it too', 
'During the whole war we ate salma', 'Sarsa is made by Russians and Kirghiz, it's sweet, tasty and goes with tea', 'No holiday happens without belishes, it's our first dish', 'the Bashkir like zyurma, Russians make it too', 'We would make zyurma in the evening', 'Today we had salamata', 'We cooked so much salamata it lasted all day' and so on. Moreover, for their love of salamata, the residents of Kuzminovka settlement got their nickname 'salamatniki' because once, while cooking their favourite dish they set their village on fire.

Lingua-cultural interaction of previously territorially segregated native population of Orenburg was clearly understood by the migrants, which was shown in their evaluation of interacting and establishing new communities. A respondent from the Saraktash region defines the settling process with a figural expression 'с ярку и с боярку' [from all around, everywhere]: 'Да как мы населялись: шли с ярку и с боярку всякие люди - и русские, и украиниьы, и мордва' [So we were settling, all peoples came from everywhere - Russians, Ukranians, Mordvins], (Moiseyev, 2019). It is most likely to mean that 'all peoples' arrived from rather obscure and distant places. V.I. Dahl describes those settlements as 'diverse' [in a bad way], (Dahl, 2000).

K.D. Zelenin also writes about geographical and social diversity in territories of later settling around Orenburg. Defining the sub-dialects of the residents of the Blagoslovennyi settlement, which was populated by the Orenburg and Samara Cossacks, the peasants from the right bank of the river Ural in Orenburg governorate, the newcomers from Tambov governorate, the Ukrainians from Kharkov and Cherkasy, the Mordvins, K.D. Zelenin concludes that in 80 years 'all this diverse rout', thanks to communal life and mutual family connections, 'resulted in a regular mass of descendants' (Zelenin, 1905).

The same description was given to the new mixed population by a female resident of Gavrilovka settlement, founded in 1840 by migrants from Kharkov governorate, which later was also populated by the families from Voronezh and Ryazan governorates. In her story she points out that the Ukrainians never had banyas [Russian saunas] and they learnt to build and use them from Russians. She concluded, 'there were Ukrainians, and now, after 140 years, we are neither Ukrainians, nor Russians, we are rootless...', (Moiseyev, 2016).

However, in our opinion, there are two articles in 'the dictionary of Orenburg oblast' (Moiseyev, 2019) that characterize Orenburg population especially well - 'нерусь' ['nеrus', 'non-Russians'] and 'обрусеть' ['obruset', to be/become Russified']. On the one hand, 'нерусь' (a collective noun for non-Russian people, or people of other nationalities) is clearly grounded with examples (e. g. 'All the nerus live in the Caucasus - the Georgians, the Armenians, the Ingush, the Chechen'), meaning peoples not common around the Orenburg region. We never encountered any contexts where this word was used to refer to any people that were present on the Orenburg lands, such as the Kazakh, the Tatar, the Bashkir, the Chuvash, the Mordvins, etc. On the other hand, the records that go along the verb 'обрусеть' allow us to define the process of 'nerus' [non-Russians] becoming or being introduced to 'rus' [Russians], which is supposed to be regarded not as an ethnic metamorphosis, but as a sort of transformation of life as the essence of all the living things: 1) on wild animals or birds - to get domesticated or tamed ('Поймаешь зайца и домой, он обрусеет и живёт [You catch a hare and bring it home, it becomes Russified and lives]'); 2) On people - to get used to new life conditions, to settle ('Когда приехали сюда, у нас (мужиков) отличка была с казаками, а сейчас уж мы обрусели [When we came here we (the men) were different from the Cossacks, but now we have become Russified']. 'Постепенно мы обрусели на новом месте. Киргизы обрусели и перестали топтать наши посевы ['Gradually we became Russified on our new place. The Kirghiz became Russified and stopped stomping our crops']. 'Киргизы обрусели, стали ездить к нам на базар' ['The Kirghiz became Russified and began coming to our market']) and so on. Ethnic and social differences do not matter while understanding the word 'obruset' (the men became Russified, the Kazakhs became Russified), but what is important is getting accustomed to new natural and householding 
phenomena, ethnocultural environment and accepting them as one's own, rejecting any hostility towards the foreign or alien, which leads not only to diversity in life but also to the world communality, developed by human interaction of many centuries.

\section{Conclusion / Results}

Therefore, while acquiring new lands, the migrants not only take upon themselves some new material world, but they also get into various contacts with their new neighbours, who, as a rule, carry different traditional cultures. Being forced to contact, if it is not violent conquering, under the condition of going past the opposition 'friend-or-foe', results in 'neighbours' starting to exchange their everyday life cultural achievements, which, in our opinion, causes certain changes in the people's consciousness. A natural linguistic contacting gains lingua-cultural meaning, as it becomes essential in the new historical and geographical conditions of developing the traditional national culture. As a result, the Orenburg region possesses a wide range of blending in dialectal features, inherited from geographically grounded differences in householding, customs, and culture.

The records of Orenburg's dialectal speech from 1950-1970s and up to the early XXI century provides the information about a varied and, as a rule, very friendly dialogue between the interacting people, which was caused by the type of contact that demanded to build up communal activities in householding and trading. Often it became personal friendly relationships, which was shown in the culinary culture, and later it resulted in establishing a tight community in a certain territory, despite the differences in the outlook and habitual traditions of householding, and against resentment and even hostility.

\section{References}

Barannikova, L.I. (2005). Govory territorii pozdnego zaseleniia i problema ikh klassifikatsii [Subdialects in the territories of later settling and the problems of their classification]. Obshchee i russkoe iazykoznanie: izbrannye raboty [General and Russian linguistics: selected works]. Moscow, KomKniga, 192-203.

Baudouin de Courtenay, I.A. (1963). O smeshannom kharaktere vsekh iazykov [On mixed nature of all the languages]. Izbrannye trudy po obshchemu iazykoznaniiu [Selected works on general linguistics]. Moscow, 1, 362-372.

Bazhenova, T.E. (2016). Naimenovaniia predstavitelei zhivotnogo mira v govorakh Samarskoi oblasti [Names of wildlife representatives in the sub-dialects of Samara oblast], In Dialektnaia leksika [Dialectal vocabulary], 27-38.

Bekasova, E.N. (2014). Ob osobennostiakh predstavleniia tiurkskikh zaimstvovanii v orenburgskikh govorakh [On the specifics of representing Turkic borrowings in Orenburg sub-dialects]. Aktual'nye problemy dialektologii iazykov narodov Rossii: Materialy XIV Vserossiiskoi nauchnoi konferentsii (Ufa, 20-22 noiabria 2014 g.) [Actual problems of dialectology of Russian people's languages: Proc. All-Russian scientific conference]. Ufa. IIIaL UNTs RAN, 34-44.

Bekasova E. N. (2018). Peculiarities of Linguistic Worldview Transformation on the Territory of Later Settling. The European Proceedings of Social and Behavioural Sciences EpSBS. WUT 2018 IX International Conference «Word, Utterance, Text: Cognitive, Pragmatic and Cultural Aspects». Orenburg. XXXIX - WUT, 548-553.

Bekasova, E.N. (2020). Osobennosti kazakhskikh zaimstvovanii v orenburgskikh russkikh govorakh [Specifics of Kazakh borrowings in Orenburg Russian sub-dialects]. Dialektologiia. Etnolingvistika. Mifologiia. Onomastika. Etimologija: materialy mezhdunarodnoi nauchnoi konferentsii [Dialectology. Ethnolinguistics. Mythology. Onomastics. Etymology: proc. Int. Scientific conference]. Ufa, Bash. Entsikl. 1, $170-173$.

Bekasova, E.N. Yakimov, P.A. (2019). Voprosy onomastiki [Issues of onomastics]. Vserossiiskaia (s mezhdunarodnym uchastiem) nauchnaia konferentsija «Chetvertye Moiseevskie chteniia» [Orenburg 
State Pedagogical University, Orenburg, Russia 4th All-Russian Conference in Memory of Boris Moiseyev]. Orenburg, 16 (3), 247-251.

Dahl, V.I. (2000). Tolkovyi slovar' zhivogo velikorusskogo iazyka [The Explanatory Dictionary of the Living Great Russian Language by Vladimir Dahl]. Moscow, Russkii Iazyk.

Moiseyev, B.A. (2005). Orenburgskaia oblastnaia dialektologicheskaia khrestomatiia (uchebnoe posobie po russkoi dialektologii) [Orenburg regional dialectological chrestomathy (a study guide on Russian dialectology). Orenburg, izd-vo OGPU, $132 \mathrm{p}$.

Moiseyev, B.A. (2010). Orenburgskii oblastnoi slovar' [Orenburg regional dictionary]. Orenburg, Izdvo OGPU, $192 \mathrm{p}$.

Moiseyev, B.A. (2013). Mestnye nazvaniia Orenburgskoi oblasti. [Local names in Orenburg oblast]. Istoriko-toponimicheskie ocherki [Historical and toponymical essays]. Orenburg, Idvatelstvo OGPU, $380 \mathrm{p}$.

Moiseyev, B.A. (2016). Toponimicheskie ocherki Orenburzh'ia. Nauchno-populiarnoe izdanie (posleslovie E.N. Bekasovoi) [Toponymical essays of Orenburg. Popular science issue (Afterword by E.N. Bekasova)]. Orenburg, 'Orenburgkaia kniga', $416 \mathrm{p}$.

Moiseyev, B.A. (2019). Orenburgskii oblastnoi slovar' [poslesl. E. N. Bekasovoi] [Moiseyev B. A. Orenburg regional dictionary [afterword by E.N. Bekasova]. Orenburg, OOO 'Orenburgskoe knizhnoe izdatel'stvo imeni G.P. Donkovtseva', 516 p.

Myznikov, S.A. (2010). Russkie govory Orenburzh'ia v polietnichnom okruzhenii [Russian sub-dialect of Orenburg in polyethnic environment], In Vestnik Rossiiskogo gumanitarnogo nauchnogo fonda [Bulletin of Russian humanitarian scientific fund], 1 (58), 187-195.

Myznikov, S.A. (2018). O leksicheskikh osobennostiakh govora iaitskikh (ural'skikh) kazakov [On the lexical peculiarities of the Ural Cossacks' sub-dialect]. Issledovania po slavianskoi dialektologii [Studies on Slavic dialectology]. Moscow, Institut slavianovedeniia, 19-20, 24-36. DOI: 10.31168/0412-1.1.3.

Myznikova, Ya. V. (2017). Spetsifika mezhetnicheskogo vzaimodeistviia v Simbirskom Zavolzh'e po dannym russkikh govorov [Specifics of inter-ethnic interactions in Simbirsk Zavolzhie according to Russian sub-dialects], In Vestnik Sankt-Peterburgskogo universiteta, Iazyk i literatura [Bulletin of SaintPetersburg University. Language and literature], 1, 38-48.

Panchenko, A.M. (2005). Ia emigriroval v Drevniuiu Rus'. Rossiia: istoriia i kul'tura. Raboty raznykh let [I migrated to Ancient Rus. Russia: history and culture. Works of various years]. Saint-Petersburg, Izdatelstvo zhurnala 'Zvezda', 544p.

Slovar' russkikh narodnykh govorov [Russian national sub-dialect dictionary], (1965-2020). 1-52, Moscow-Leningrad.

Vestnik of Orenburg State University (2015). 2-4. Available at http://vestospu.ru.

Yakimov, P.A. (2017). Russkie govory kak otrazhenie natsional'noi mental'nosti [Russian sub-dialects as reflection of national mentality]. Orenburg, 'Orenburgskaia kniga', $157 \mathrm{p}$.

Yakimov, P.A. (2018). Chetviortye Moiseevskie chteniia: natsional'nye i regional'nye osobennosti iazyka: $v 2$ chastiah. Materialy Vserossiiskoi (s mezhdunarodnym uchastiem) nauchnoi konferentsii [Fourth Moiseyev's Readings: national and regional peculiarities of the language: in 2 parts. Materials of the AllRussian (with international participation) scientific conference]. Orenburg, 'Orenburgskaia kniga', 1-2, $225 \mathrm{p}$.

Yakimov, P.A. (2019). Piatye Moiseevskie chteniia: istoriko-kul'turnyi i lingvisticheskii landshaft regiona: Materialy Mezhdunarodnoi nauchnoi konferentsii, posviashchionnoi 100-letiiu Orenburgskogo gosudarstvennogo pedagogicheskogo universiteta, 275-letiiu Orenburgskoi gubernii i 285-letiiu obrazovaniia Orenburgskoi komissii [Fifth Moiseyev's Readings: Historical, Cultural and Linguistic Landscape of the Region: Materials of the International Scientific Conference dedicated to the 100th anniversary of the Orenburg State Pedagogical University, the 275th anniversary of the Orenburg governorate and the 285 th anniversary of the formation of the Orenburg Commission]. Orenburg, 'Orenburgskaia kniga'. $224 \mathrm{p}$.

Yakimov, P.A., Bekasova, E.N. (2021). Shestye Moiseevskie chteniia: Materialy Mezhdunarodnoi nauchnoi konferentsii studentov i prepodavatelei, posviashchionnoi 95-letiiu so dnia rozhdeniia kandidata filologicheskikh nauk, dotsenta Borisa Aleksandrovicha Moiseeva [Sixth Moiseyev's Readings: Materials of 
the International Scientific Conference of Students and Teachers, dedicated to the 95th birthday anniversary of the candidate of philological sciences, associate professor Boris Aleksandrovich Moiseev]. Orenburg, 'Orenburgskaia kniga'. $154 \mathrm{p}$.

Zelenin, D.K. (1905). O govore orenburgskikh kazakov [On the sub-dialect of Orenburg Cossacks], In Russkii filologicheskii vestnik [Russian philological bulletin]. LVI, (3-4), 234-245. 